\title{
Preservice Social Studies Teachers’ Opinions Regarding History Education*
}

\author{
Eray Alaca ${ }^{1}$, Tercan Yildirim ${ }^{2}$ \\ ${ }^{1}$ Department of Turkish and Social Sciences Education, Faculty of Education, Giresun University, Giresun, Turkey \\ ${ }^{2}$ Department of Turkish and Social Sciences Education, Faculty of Education, Ahi Evran University, Kursehir, Turkey \\ Correspondence: Eray Alaca, Department of Turkish and Social Sciences Education, Faculty of Education, Giresun \\ University, Giresun, Turkey.
}

Received: February 12, 2018

doi:10.11114/jets.v6i4.3021
Accepted: March 6, $2018 \quad$ Online Published: March 16, 2018

URL: https://doi.org/10.11114/jets.v6i4.3021

\begin{abstract}
In Turkey, preservice social studies teachers take history education courses such as Revolution History and Kemalism I-II, Ancient History and Civilization, Pre-Islamic Turkish History and Culture, History of Turkish Education, History of Medieval Age, Ottoman History and Civilization I-II, New and Contemporary History, Contemporary World History, and History of Turkish Republic I-II during their undergraduate education. The purpose of this study was to reveal preservice social studies teachers' opinions regarding how these courses were taught. Within this scope, their perceptions of how these courses were taught and their opinions regarding how history courses should be taught were tried to be determined. The participants of this study involved 125 third and fourth-year undergraduates studying social studies education of a faculty of education at a state university. One of the qualitative research designs, phenomenology was used in this study. The data were collected using a semi-structured interview form. During the interviews, the participants were asked to respond three questions: "What is instruction?", "How are history courses taught in your department?", and "how should the history courses be taught?" The data were analyzed using descriptive analysis technique. Direct quotations were used and the emerging themes were presented under some categories in Findings section.
\end{abstract}

Keywords: history education, preservice social studies teachers, primary education

\section{Introduction}

Social studies is a "primary education lesson: created with the goal of helping individuals to realize their social existence; involving topics such as history, geography, economics, sociology, anthropology, psychology, philosophy, politics, law, and citizenship; uniting learning fields under a unit or theme; examining the interaction of human with their social and physical environment within the context of past, today, and future; and created based on the integrated education approach" (as cited in Er \& Bayindir, 2015a; MEB, 2006). In other words, the main purpose of social studies lesson is to improve students' basic knowledge, skills, attitudes, and values about social life, and raise decent and responsible citizens (Donmez, 2003).

Social studies lesson is based on history, geography, and citizenship. Some sort of historical consciousness is developed through history education since it mainly determines the quality of future citizens. Historical consciousness has a vital role in the adoption of some behaviors such as patriotism and praising own nation, which are expected from students. Moreover, history topics are important in the transmission of cultural heritage. History education help students understand today by questioning the past and develop some skills such as democratic, analytic, and critical thinking (Elban, 2015; Er \&Bayindir, 2015a; Er \&Bayindir, 2015b; Kaya, 2015; Ulusoy, 2009; Dilek, 2007; Demircioğlu, 2005).

While the significance of history education is emphasized within the scope of the goals of history education, a body of research reveals that history is tried to be taught with a teacher-centered approach involving a great deal of information and depending on memorization (Ozbaran, 2008; Demircioğlu, 2005; Tekeli 1998; Tuncay, 1998; Paksoy, 1997). This situation makes students think that "the past is useless." Although written and visual materials are used in lessons to

*This paper was presented at the IX. International Congress of Educational Research in 11-14 May 2017/Ordu/Turkey. 
attract students' attention, they perceive history lessons as a course requiring memorization, using direct instruction, teacher-centered, and depending on textbooks (Ulusoy, 2014).

The introduction of a course called social studies for the first time in 1968 brought up the need for teachers. At first, history and geography teachers taught social studies. After the 1997 reform in faculties of education and transition to 8-year compulsory primary education, the programs to train social studies teachers were founded in faculties of education, and they began to be employed. Then, 1998 social studies education bachelor program, which involved the use of central and common curriculum in social studies education programs and projected social studies preservice teachers to take Turkish courses as the minor, went into effect. Social studies curriculum for primary and middle schools was renewed in 2005 based on constructivism, and it began to be implemented in 2006 (Kaymakci, 2012; Tonga, 2012; CoHE, 2006; CoHE, 1998).

The aforementioned renovations in primary and secondary education revealed the requirement to carry out history and revolution history and Kemalism courses in accordance with constructivist principles. With these new regulations, history courses aimed at transmitting national identity and national culture and training students who could feel belonging, question and criticize historical events and analyze the reasons behind a problem (MNE, 2005). As can be understood, the new curriculum required students to perceive history like a historian and use thinking skills rather than memorization of information in textbooks. Thus, a student-centered approach is to be adopted, which results in changes in the expectations from preservice social studies teachers because their experiences as undergraduates have a great effect on their approaches on teaching once they become teachers. Within this scope, the primary goal is to develop positive attitudes in preservice teachers who will try to raise decent citizens in addition to their professional knowledge and skills, and it courses provided during undergraduate education should be regulated in such a way that they could serve this purpose (Akhan, 2015). What is expected from preservice social studies teachers are "having adequate knowledge and equipment for education, guiding students, and motivate students by creating appropriate learning settings" (as cited in Er \& Bayindir, 2015a; Fidan \& Erden, 1998).

When the social studies education undergraduate programs are examined, it can be observed that preservice teachers are provided with a variety of history courses during their education for four years (Table.1).

Table1. History Courses Involved in Social Studies Education Undergraduate Programs

\begin{tabular}{lll}
\hline Course & Year & Course Hour \\
\hline Revolution History and Kemalism I & 1 & 2 \\
Revolution History and Kemalism II & 1 & 2 \\
Ancient History and Civilization & 1 & 2 \\
Pre-Islamic Turkish History and Culture & 2 & 2 \\
History of Turkish Education & 2 & 2 \\
History of Medieval Age & 2 & 4 \\
Ottoman History and Civilization I & 3 & 2 \\
Ottoman History and Civilization II & 3 & 2 \\
New and Contemporary History & 3 & 2 \\
Contemporary World History & 3 & 2 \\
History of Turkish Republic I & 4 & 2 \\
History of Turkish Republic II & 4 & 2 \\
\hline
\end{tabular}

The purpose of this study was to reveal preservice social studies teachers' opinions regarding how these courses were taught. Within this scope, their perceptions of how these courses were taught and their opinions regarding how history courses should be taught were tried to be determined. Therefore, it is considered that determining the shortcomings of history education and coming up with solutions are important for social studies curriculum to reach its goals.

\subsection{Purpose}

The purpose of this study was to reveal preservice social studies teachers' opinions regarding history education. Within this scope, the research questions are presented below:

1. What are the opinions of preservice social studies teachers regarding the concept of instruction?

2. What are the opinions of preservice social studies teachers regarding how history courses are taught in their department?

3. What are the opinions of preservice social studies teachers regarding how the history courses should be taught?

\section{Method}

One of the qualitative research designs, phenomenology was used in this study. Phenomenology focuses on the phenomena that we are aware but don't have a detailed understanding. The data were analyzed using descriptive analysis technique (Yildirim \& Simsek, 2016; Creswell, 2013). This technique enables organizing the data in 
accordance with the themes of research questions and presenting them based on these themes or dimensions (Yildirim \&Simsek, 2016). Within this scope, the data obtained using open-ended items were coded and presented using percentages. Additionally, direct quotations from preservice social studies teachers(PSST) were presented as well.

\subsection{Participants}

The participants of this study involved 125 third and fourth-year undergraduates studying social studies education of a faculty of education at a state university in Turkey. Of all the participants, $74(59.2 \%)$ were male and $51(40.8 \%)$ were female.

\subsection{Data Collection}

The data were collected using a semi-structured interview form involving three items. The literature was reviewed while creating the interview items to support internal validity of the research. Moreover, the opinions of two academics were taken.

\subsection{Sampling Procedures}

The data were analyzed using descriptive analysis technique. In descriptive analyses, the data obtained from interviews are presented without changes using direct quotations (Yildirim \& Simsek, 2016). The goal of this process is to present the data obtained from interviews or observations to the reader in a planned and interpreted way. The data are classified, summarized, and interpreted based on the predetermined themes. Cause effect relationship is founded among findings, and phenomena are compared when necessary (Yildirim \& Simsek, 2016; Creswell, 2013; Guler, Halicioglu, and Tasgin, 2013). The data of this study were classified under specific themes, and interpreted by describing.

\section{Results}

In this section, the data collected to determine preservice social studies teachers' opinions' regarding the history courses they took in their faculties were described.

\subsection{Preservice Social Studies Teachers' Opinions Regarding the Concept of Instruction}

When the preservice social studies teachers' opinions regarding the concept of instruction were examined, four different themes emerged, which are presented in Table 2.

Table 2. Preservice Social Studies Teachers' Opinions regarding the Concept of Instruction

\begin{tabular}{lcc}
\hline Theme & F & \% \\
\hline Conveying predetermined information to students within a plan and program at schools & 67 & 53,6 \\
The creation and construction of one's own knowledge within a lifelong process & 27 & 21,6 \\
The process of relatively permanent change in behavior & 15,2 \\
$\begin{array}{l}\text { Organizing activities that will facilitate learning, providing materials and tools, and leading learning, } \\
\text { guiding }\end{array}$ & 12 \\
\hline Total & 9,6 \\
\hline
\end{tabular}

Of all the participants, 67 preservice social studies teachers (53.6\%) defined instruction as "conveying predetermined information to students within a plan and program at schools." Some of these definitions are presented below:

PSST4: Conveying information to help individuals reach a specific goal.

PSST6: Equipping individuals with information about specific topics.

PSST11: Conveying predetermined topics to individuals in a place.

PSST17: Flow of information from someone who is specialized and knowledgeable at a topic to students using a variety of methods and materials.

PSST26: Conveying information to students through various ways.

PSST36: Telling the accumulation of knowledge possessed by someone to other people in a comprehensible way.

PSST37: Giving and transmitting information about a topic.

PSST52: Transmission and teaching of knowledge and skills to the students.

PSST63: Conveying information to people, which would help them in the future.

PSST83: Transmission of information in a setting where the learner and teacher are present.

PSST104: Conveying information in curriculum to students.

12 preservice social studies teachers $(9.6 \%)$ defined instruction as "organizing activities that will facilitate learning, providing materials and tools, and leading learning, guiding." Some of these definitions are presented below:

PSST5: Guiding students by individuals who are specialized in their fields with reference to their knowledge and experience. 
PSST7: Guiding through learning.

PSST14: Organizing the activities that will facilitate learning, and guiding through learning.

PSST58: Leading someone to achieve a goal.

PSST71: Guiding students during learning activities and providing instructional materials.

PSST108: Guidance conducted by professionals.

46 preservice social studies teachers (36.8\%) were determined to have misconceptions. 27 of them (21.6\%) defined instruction as "creation and construction of one's own knowledge within a lifelong process" and confused instruction with learning. Some of these definitions are presented below:

PSST2: The process of one's comprehension and internalization of some information through its own life, and practice them in life.

PSST25: Information that individual learned for his/her lifetime.

PSST27: Learning some concepts within a program by students.

PSST31: It is what people gained from their birth to death.

PSST42: Organizing activities that will make things easier for people and overcome the deficiencies.

PSST44: Individuals' efforts of obtaining information to have physical and spiritual competency.

PSST50: One's development of itself in terms of knowledge, culture, and morality.

PSST77: Constructing information obtained from the environment in one's own mind.

PSST120: Acculturation of individual through his/her interactions with the environment.

Of the preservice social studies teachers with misconceptions, $19(15.2 \%)$ defined instruction as "process of relatively permanent change in behavior", which indicated that they confused instruction with education. Some of these definitions are presented below:

PSST10: Making permanent changes in individuals' behaviors.

PSST15: Change in behavior.

PSST32: Improving one's knowledge and skills that will affect his/her behaviors.

PSST47: Positive change in behavior.

PSST74: Acquisition of desired behaviors as a result of interaction with environment.

PSST107: The act of behavior modification at a specific time and setting.

PSST113: The process of behavior modification within a plan and program.

PSST123: Ensuring one's adaptation to environment by behavior modification.

3.2 Preservice Social Studies Teachers' Opinions Regarding How History Courses Are Taught in Their Department

As a result of the responses given to the question "how are history courses taught in your department", two themes emerged, which can be seen in Table 3.

Table 3. Preservice Social Studies Teachers' Opinions Regarding How History Courses are taught in their Department

\begin{tabular}{|c|c|c|}
\hline Theme & $\mathbf{F}$ & $\%$ \\
\hline Through lectures by the instructor & 92 & 73,6 \\
\hline Through the presentations by the undergraduates ${ }^{1}$ & 33 & 26,4 \\
\hline Total & 125 & 100 \\
\hline
\end{tabular}

Preservice social studies teachers, who indicate that the courses are conducted through the lectures given by the instructor (73.6\%), explain this situation as:

PSST44: It is conducted through the teacher's lecture.

PSST98: Mainly, direct instruction is used.

PSST97: It is tried to convey information from teacher to students.

\footnotetext{
${ }^{1}$ In the university where this study was conducted, all of the classrooms have projectors and they can be used actively.
} 
PSST21: It is taught by lectures or with a memorization system.

PSST24: The teachers lectures. Gives all details about the topic. The student is only a passive listener.

PSST89: It is mainly teacher-centered, the teacher lectures all the time. The student is passive and silent.

PSST88: The instructors just give lecture and go.

PSST87: It is lectured in a boring way. Through direct instruction.

PSST37: The lectures aren't comprehended well due to verbal expression.

PSST48: Most of the time, the teachers lecture themselves.

PSST34: In a lesson where the teacher is active and based on listening.

PSST69: Although different teachers teach the lessons, most of them have a memorization-based approach.

PSST51: Most of the time, the teacher tells about historical events.

PSST74: Memorization-based education which is the traditional education style is used.

PSST57: Teacher-centered and using slides.

PSST15: It is conducted by teacher using a projector.

Preservice social studies teachers, who indicate that the courses are conducted through the presentations made by the undergraduates" exemplify this situation as:

PSST13: Through presentations made by students.

PSST27: The history courses are conducted by the transmission of topics through the presentations made by groups of students.

PSST42: Through presentations, student-centered way.

PSST111: Through expository instruction made by students using slides.

PSST59: By making students present the topic.

PSST118: The students select a topic and present it in the classroom.

\subsection{Preservice Social Studies Teachers' Opinions Regarding How the History Courses Should Be Taught}

As a result of the responses given to the question "how should history courses be taught", four themes emerged, which can be seen in Table 4.

Table 4. Preservice Social Studies Teachers' Opinions Regarding How the History Courses should be taught

\begin{tabular}{lll}
\hline Theme & F & \% \\
\hline Using Instructional technologies and visual-audial materials & 63 & 50,4 \\
Using active learning methods & 44 & 35,2 \\
Through field trips & 11 & 8,8 \\
Through frequent repetitions & 7 & 5,6 \\
\hline Total & $\mathbf{1 2 5}$ & $\mathbf{1 0 0}$ \\
\hline
\end{tabular}

Of all the preservice social studies teachers in the study, 63 participants (50.4\%) indicated that instructional technologies and visual-audial materials should be used frequently:

PSST12: Interesting short videos should be watched in lessons.

PSST17: Historical events should be explained using visual presentations.

PSST58: Materials such as photos, CDs, and videos should be used.

PSST60: History topics should be taught using maps.

PSST72: History courses should be taught by using various visuals and animations.

PSST85: Documentaries related to the topic should be watched.

PSST97: Various concept maps should be used.

PSST98: Technological materials, overhead projectors, projectors, and interactive smartboards should be used.

PSST110: History courses should be supported by the pictures, cartoons, coins etc. of the related period.

$44(35.2 \%)$ of the preservice social studies teachers indicated that active learning methods such as discussions, evidence-based learning, learning by doing and experiencing, and drama rather than memorization should be incorporated in history courses: 
PSST1: History courses should be conducted in a way that doesn't bore students with mutual exchange of ideas.

PSST34: The students should be involved in the lesson actively and encouraged to carry out research.

PSST45: The students should be viewed as little historians.

PSST51: Historical topics should be taught through evidence-based instruction.

PSST56: It should focus on students and based on discussions.

PSST93: The topics should be presented with examples from the past and the historical events should be impersonated.

PSST105: The students should be more active in the lesson instead of the teacher, and techniques such as roleplaying and drama should be incorporated in historical topics.

PSST125: Question and answer method should be used and students' opinions should be taken.

$11(8.8 \%)$ preservice social studies teachers indicated that the field trips should be used in history courses.

PSST74: The historical places should be visited and those places where the events took place should be examined.

PSST85: The history courses should be conducted using field trips and visiting the culturally important places.

PSST97: Teachers should conduct activities in historical places and museums.

PSST108: The history courses should be taught in places where the event took place.

7 (5.6\%) of the preservice social studies teachers indicated that the history courses should involve periodical repetitions.

PSST7: Various examples should be presented and the topics should be taught over and over again to improve the retention.

PSST111: It is frequently repeated since the topics in history course is difficult to remember.

PSST121: Previous topics should be repeated since the historical events are interrelated.

\section{Conclusion, Discussion, and Recommendations}

The results showed that the majority (53.6\%) of preservice social studies teachers perceived instruction as conveying information to students within a plan and program at school. Other preservice teachers viewed it as organizing activities to facilitate learning and guiding. On the other hand, some of them confused instruction with learning and teaching, which indicated that they had misconceptions. This is a frequent situation especially in social sciences (Candan, 2014). The course "concept teaching" should be compulsory in the social studies education department to overcome misconceptions ${ }^{2}$. Thus, the undergraduates will learn that every concept cannot be used interchangeably and there is a difference between similar and real meanings.

The majority (73.6\%) of participants' responses given to the question "how are history courses taught in your department" were direct instruction. They expressed that the courses were conducted using slides which are read by the instructor or just lecturing. This situation creates an environment where the course is conducted in a way that as if the textbook was read, which makes the lessons boring. On the other hand, some participants (26.4\%) stated that the topics were distributed to students individually or in groups for them to present the topics using slides, which made students active in the classroom. Based on the constructivist approach, history courses will be more interesting and enjoying by this way compared with teacher-centered instruction.

With reference to preservice teachers' four-year undergraduate education and school experience courses in their final year, they were asked "how should history courses be taught." Half of the students (50.4\%) expressed that visual and audial materials should be used in history courses. Some of them (35.2\%) indicated that evidence-based learning and learning by doing methods which aren't involving memorization should be used. Another part of participants (8.8\%) indicated that field trips should be used in history education. Interestingly, a small portion of participants (5.6\%) stated that frequent repetitions should be used in history course, which meant that they adopted a memorization based approach. However especially in history courses, a student and learning-centered approach in which the active participation of students is ensured should be adopted based on constructivist learning approach. The memorization makes history courses boring and unpleasant. Within this scope, constructivist approach should me emphasized more in faculties of education.

In conclusion, it is observed that the constructivist approach wasn't adopted by preservice teachers studying at faculties of education of universities especially for history courses and it remained at a theoretical level. This situation supports

\footnotetext{
2 The course "concept teaching" is provided to students as an elective course in the departments of social studies
} education at some universities in Turkey. 
the studies arguing that there is a problem in training social studies teachers, history courses doesn't attract students, and the courses are taught using teacher-centered and traditional methods (Demircioglu, 2005; Guler, 2005; Ozbaran, 1998; Tekeli, 1998a; Tekeli, 1998b; Tuncay, 1998; Paksoy, 1997). The majority of preservice social studies teachers indicated that undergraduate history courses are taught using direct instruction method and depending on the textbook. Some of the preservice teachers expressed that the history courses were taught by reading the slides which were prepared by the instructor earlier. This is no different from reading the textbook. Thus, history courses, about which students already have prejudices, become more boring. However, the research emphasizes that beyond textbooks, the use of communication devices such as computer, internet, and television and materials such as tapes and cds will facilitate students reach information. Moreover, it is expressed that visual presentations, overhead projectors, and computers will enrich the lesson and contribute to effective learning (Elban, 2017; Er and Bayindir, 2015a, Akbaba, 2003; Ozalp, 2000). Students can be encouraged to participate actively and the courses can be made more interesting and enjoying. Animations, maps, interviews with primary sources and CD-DVDs involving the records of these interviews can enrich the lesson and keep students' attention and active participation.

\section{References}

Akbaba, B. (2003). Photograph use in history teaching. Unpublished master's degree thesis. Gazi University Institute of Education Sciences, Ankara.

Akhan, N. E. (2015). Views of social studies teacher candidates on social studies undergraduate program. The Journal of Academic Social Science Studies, 32(3), 267-289.

Candan, A. S. (2014). Concept Teaching in History Courses. In (Ed. Muammer Demirel) History Teaching Methods. (pp. 56-74). Ankara: Pegem Akademi

Council of Higher Education [CoHE]. (2006). Social studies teaching degree program. Ankara.

Council of Higher Education[CoHE]. (1998). Education faculty teacher training degree programs. Ankara.

Council of Higher Education[CoHE]. (1998). Faculty of education teacher training undergraduate programs. Ankara.

Creswell, J. W. (2013). Qualitive inqury and researh design: Choosing among five approaches. Sage Publications.

Demircioglu, I. H. (2005). Student-centered approaches in history teaching. Ankara: Ani Publishing.

Dilek, D. (2007). Learning in history lessons and development of thought. Ankara: Nobel Akademik Publishing.

Donmez, C. (2003). Social sciences and social studies. In (Ed. Cemalettin Sahin) Social Studies Subject Area Course Review Guide. Ankara: Gündüz Education and Publishing.

Elban, M. (2015). Some thoughts on history education and patriotism. International Journal of Turkish Literature Culture Education, 4(3), 1302-1319. https://doi.org/10.7884/teke.495

Elban, M. (2017). University Students' Views on the Education and Teaching of Civilization History: Bayburt University Education Faculty Sample. Journal of Education and Training Studies, 5(10), 123-136. https://doi.org/10.11114/jets.v5i10.2560

Er, A. R., \& Bayindir, N. (2015a). The determination of social studies teachers' views on physical conditions, materials and teacher factor regarding teaching history subjects. Usak University Journal of Educational Research, 8(4), 88-103.

Er, A. R., \& Bayindir, N. (2015b). Determining the opinions of teachers regarding to teaching history subjects in the context of social studies. Usak University Journal of Social Sciences, 8(4) 357- 379.

Guler, A., Halicioglu, M. B., \& Tasgın, S. (2013). Qualitate research in social sciences. Ankara: Seçkin Publishing.

Guler, I. (2005). Function of history and teaching at society. İstanbul: Elif Bookstore.

Kaya, R. (2015). The aims of history teaching. In (Ed. M. Demirel) History Teaching Methods (pp. 37-56). Ankara: Pegem Akademi.

Kaymakc1, S. (2012). A Content Evaluation of Social Studies Teacher Education Programs. International Social Sciences Education of Journal, 2(1), 45-61.

Miles, M. B, \& Huberman, A. M. (1994). Qualitative data analysis: An expandedsourcebook. (Second Edition). California: Sage Publications Inc.

Milli Egitim Bakanligi(MEB)[Ministry of National Education(MNE)].(2005). Primary school social studies course teaching program and guide. Ankara: State Books Directorate Print house.

Milli Egitim Bakanligi(MEB)[Ministry of National Education(MNE)].(2006). Primary school social studies 5th grade 
teacher manual book (Second Edition). Ankara: Saray Typography.

Ozalp, O. (2000). History education in primary schools and high schools, restructuring of history teaching. Ankara: Turkiye Ekonomik ve Toplumsal Tarih Vakfi.

Ozbaran, S. (1998). Why and how history? In (Ed. S. Özbaran) History teaching and textbooks. (pp. 25-33). İzmir: Dokuz Eylul Publishing.

Paksoy, A. (1997). Unity in Education and History Education. Journal of Abece, 133(12).

Parlak, I. (2005). Education in Kemalist Ideology. Ankara: Turhan Bookstore.

Safran, M. (2015). Glance to social studies education. In (Ed. B.Tay - A. Ocal) Teaching of Social Studies through Private Teaching Methods (pp. 1-18). Ankara: Pegem Akademi.

Tekeli, I. (1998a). What are the purposes of history teaching on the globalizing in the World? In (Ed. Salih Ozbaran) History teaching and textbooks. (pp. 35-43), İzmir: Dokuz Eylül Publishing.

Tekeli, I. (1998b). History consciousness and youth. İstanbul: Tarih Vakfi Yurt Publishing.

Tonga, D. (2012). Evaluation of social studies education undergraduate program. The Journal of Turkish Educational Sciences, 10(4), 780-803.

Tuncay, M. (1998). Ideas for improving history teaching. In (Ed. Salih Ozbaran) History teaching and textbooks. (pp. 55-57). İzmir: Dokuz Eylul Publishing.

Ulusoy, K. (2009). New Approaches in Social Studies Education. Ankara: Pegem A Publishing.

Ulusoy, K. (2014). History teaching in the new social studies program. In (Ed. R.Turan- A. M. Sunbul- H. Akdag). New Approaches in Social Studies Education-1 (pp. 299-321). Ankara: Pegem Akademi.

Weiner, R. G. (1995). History: teaching and methods. https://files.eric.ed.gov/fulltext/ED387402.pdf.

Yildirim, A., \& Simsek, H. (2016). Qualitative research methods in the social sciences. Ankara: Seckin Publishing.

\section{Copyrights}

Copyright for this article is retained by the author(s), with first publication rights granted to the journal.

This is an open-access article distributed under the terms and conditions of the Creative Commons Attribution license which permits unrestricted use, distribution, and reproduction in any medium, provided the original work is properly cited. 